\title{
Long-term culture-initiating cells (LTC-IC) produced from CD34+ cord blood cells with limiting dilution method
}

\author{
Kısıtl $\iota$ dilüsyon yöntemi ile CD34+ kordon kanı hücrelerinden uzun- \\ dönemli kültür-başlatan hücreler (UDK-BH) üretimi
}

\author{
Gülderen Yanıkkaya Demirel1, Tülin Budak-Alpdoğan², Sema Aktaş¹, Mahmut Bayık3 \\ 1Yeditepe University, Stem Cell Laboratory of Hematology Department, Istanbul, Turkey \\ 2University of Medicine and Dentistry of New J ersey, Department of Medicine, New J ersey, USA \\ 3Marmara University, Department of Internal Medicine, Hematology-Immunology Section, Istanbul, Turkey
}

\begin{abstract}
O bjective: Even though much progress has been made in defining primitive hematologic cell phenotypes by using flow cytometry and clonogenic methods, the direct method for study of marrow repopulating cells still remains to be elusive. Long Term Culture-Initiating Cells (LTC-IC) are known as the most primitive human hematopoietic cells detectable by in vitro functional assays.

Materials and Methods: In this study, LTC-IC with limiting dilution assay was used to evaluate repopulating potential of cord blood stem cells.

Results: CD34 selections from cord blood were completed succesfully with magnetic beads $(73,64 \% \pm 9,12)$. The average incidence of week 5 LTC-IC was 1: 1966 CD 34+ cells (range 1261-2906).

Conclusion: We found that number of LTC-IC obtained from CD34+ cord blood cells were relatively low in numbers when compared to previously reported bone marrow CD34+ cells. This may be due to the lack of some transcription and growth factors along with some cytokines and chemokines released by accessory cells which are necessary for proliferation of cord blood progenitor/stem cells and it presents an area of interest for further studies. (TurkJ Hematol 2010; 27: 234-41)
\end{abstract}

Key words: Stem cell, cord blood, LTC-IC, limiting dilution, CFU assay, cytometry

Received: May 24, 2010

Accepted: August 19, 2010

\section{Özet}

A maç: A kım hücre ölçer ve klonojenik yöntemler kullanımı ile öncül hematolojik hücre fenotiplerinin tanımlanmasında çok aşama kaydedilmiş olmasına rağmen, kemik iliğini yenileyen hücrelerin doğrudan bir yöntemle tanımlanması henüz mümkün olmamaktadır. U zun Dönemli Kültür-Başlatan H ücreler (UDK-BH) in vitro fonksiyonel yöntemlerle saptanabilen en öncül insan hematopoietik hücreleridir.

Yöntem ve G ereçler: Bu arastırmada, kordon kanı kök hücrelerinin kemik iliğini yenileyen hücre yeteneğini ölçümlemek üzere kısttlı dílüsyon ile U DK -BH yöntemi uygulanmıștır.

Bulgular: Kordon kanından CD34+ hücrelerin seleksiyonu manyetik boncuklarla basarı ile gerceklesstiril-

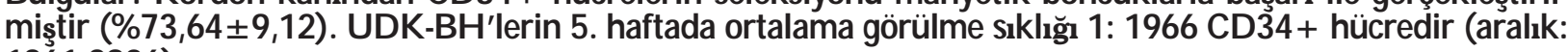
1261-2906). 
Sonuç: CD34+ kordon kanı hücrelerinden elde edilen U DK -BH sayısı daha önce yayınlarda bildirilen kemik iliği hücreleri değerlerinden daha düsük düzeyde saptanmıstır. Bu bulgunun proliferasyon için gerekli olan sinyal transkripsiyon molekülleri, büyüme faktörleri, kemokin ve sitokinlerin aksesuar hücreler tarafından salınarak ortamda olmamasına bağlı olduğu düşünülmüştür. Bu alanda gelecekte daha çok araştırma yapılması bilgilerimizin artmasını sağlayacaktır. (Turk J Hematol 2010; 27: 234-41)

Anahtar kelimeler: Kök hücre, kordon kanı, LTC-IC, kısıtlı dilüsyon, CFU kültürü, akan hücre ölçer

\section{Introduction}

Although much progress has been made in defining primitive hematologic cell phenotypes using flow cytometry and clonogenic methods, a direct method for study of marrow repopulating cells remains elusive. The long-term culture-initiating cells (LTC-IC) are the most primitive human hematopoietic cells detectable by in vitro functional assays. The validity of the LTC-IC assay is dependent on the existence of a linear relationship between the endpoint measured (clonogenic cell output as assessed after 5 weeks of culture) and the number of LTC-IC in the original test suspension down to limiting numbers of LTC-IC. To evaluate cord blood stem cells for their repopulating potential, we used limiting dilution assay (LDA) for LTC-IC. We believe that identification of defined conditions for extensive and rapid amplification of these cells would help in analyzing the benefit of these cells for therapeutic applications in the future [1-3].

LDAs are designed to define an unknown frequency of effector cells in a population. As described by Frisan et al. [4], "LDA are dose-response assays that allow detection of an all-or-none (positive or negative) immunoresponse in each individual culture within replicates that vary in the number of responder cells tested. The frequency of positive cultures is not informative because it is never clear whether one or more precursors in the culture well are giving the positive response. The negative response instead demonstrates that there are no precursors of a given specificity. Therefore, the evaluation of the cell frequency in the original population is possible by determining the number of cultures that are negative in the experiment". The LDA method for LTC-IC was the method of choice in our study to achieve more efficient results.

The type of the feeder layer, cell concentration, presence of accessory cells, change of culture media, and additional growth factors in the media are important for the proliferation of LTC-IC in culture media [3]. While many different cell lines have been published previously as feeder layer [4], it has been reported that the murine fibroblast M210-B4 cell line can support the maintenance of LTC-IC from human bone marrow as effectively as standard human marrow adherent cells [5].

\section{M aterials and M ethods}

\section{Sample Collection}

Seventeen cord blood samples were collected from healthy mothers delivering in Zeynep Kamil Obstetrics Hospital, İstanbul, after their permission was obtained. An ethical committee approval (021098/90) was provided from Marmara University Medical Faculty Ethical Committee. Collections were made when placenta was still in utero. No samples were collected from mothers with obstetric complications or from those with a history of hepatitis C infection or inherited disease. Gender of the baby was not considered in the collection and evaluation. After the cord was clamped from two distal sites, collection was performed with a $50 \mathrm{ml}$ syringe containing phosphate-buffered solution-ethylenediaminetetraacetic acid (PBS-EDTA), and 40-100 ml blood was collected from each cord Samples less than $40 \mathrm{ml}$ were not processed. Samples were transported at $18-25^{\circ} \mathrm{C}$ in specific transport boxes.

\section{Blood Count from the Collected Cord Blood Samples}

All cord blood samples were counted with automated cell counter (Coulter AcT cell counter) within 2 hours (h) of sample collection. Cell counts were also performed after erythrocyte lysis and CD34+cell selection. Cell viability was measured with trypan blue dye after each processing. Trypan blue stock solution was diluted in a 3:4 ratio with isotonic saline. Under the microscope, those cells staining blue were counted as dead cells. 


\section{Immunophenotyping of Cord Blood Cells}

For immunophenotyping, cord blood samples were labelled with CD45, CD34, HLA-DR, CD38, CD71, CD90, and CD135 after blood count. Cell concentrations were adjusted to $<5 \times 10 \% / \mathrm{ml}$. All of the antibodies and absolute count beads (FlowCount Fluorospheres) were obtained from Beckman Coulter, Turkey. Since all of the antibodies, except CD135, were in conjugated form, direct staining method was used. CD135 tube was labelled with goat anti mouse-FITC as secondary antibody. DHR123 was obtained from Molecular Probes, Eugene, OR, USA. Tubes were prepared with the following combinations after careful titrations of antibodies: IgG1-FITC/IgG1-PE (isotypic control), CD45-FITC/CD34-PE, Rhodamine (Rhd)123/CD34PE, CD34-FITC (for absolute counts), CD34-FITC/ HLA-DR-PE, CD34-FITC/CD38-PE, CD71-FITC/CD34PE, CD90-FITC/CD34-PE, and CD135-FITC/CD34-PE. Flow count fluorospheres were used for absolute CD34 counts (concentration 1043 beads/ $\mu$ l). After labelling with antibodies, tubes were incubated at room temperature $\left(18-25^{\circ} \mathrm{C}\right)$, in the dark for $15 \mathrm{~min}$ utes (min); then, a lysing solution (ammonium chloride, $\mathrm{pH}$ 7.2-7.4) was added. After $10 \mathrm{~min}$ of incubation, cells were washed twice, and cell fixation was done with 1\% PFA (paraformaldehyde, Sigma) in a 1:1 concentration.

For absolute counts, $100 \mu \mathrm{l}$ of flow count fluorospheres were vortexed and added to CD34 absolute count tubes, and absolute counts were calculated using the following formula:

Absolute Count $=$ Total counted cell number $\times$ Concentration of flow count Total counted fluorospheres fluorospheres

Immunophenotyping analyses were performed with EPICS XL-MCL flow cytometry system (Beckman Coulter, USA). Before analysis, Flow Check beads were used for checking the laser alignment, and Flow Set beads were used for fluorescence calibration and to minimize the day-to-day variations.

For each tube, cytometric measurements were made using SS/FS (Side Scatter-Granularity/Forward Scatter-Size), FL1 (green fluorescence) and FL2 (orange fluorescence) parameters. For CD34 counts, 50,000 nucleated cells were counted in each tube. All of the list mode data were recorded and later analyzed with System 2.0 software (Beckman Coulter, Turkey).

\section{Selection of CD34+ Cord Blood Cells with Magnetic Beads}

All of the cell selection and follow-up procedures were performed in a clean environment inside the laminar air flow hood.

Magnetic separation of the cell suspensions: Magnetic separation beads were obtained from Miltenyi, Germany. To prevent non-specific or Fc receptor (FCR) binding, $100 \mu \mathrm{l}$ of FCR blocking reagent was added onto cells. For each $10^{8}$ cells, $100 \mu$ l of CD34 MultiSort MicroBeads were added, mixed well and incubated at $+4^{\circ} \mathrm{C}$ for 30 min. The Miltenyi LS columns used for magnetic separation were able to select a total of $2 \times 10^{9}$ cells. LS columns, which were kept at $-20^{\circ} \mathrm{C}$ the night before the cell processing, were taken out of the $-20^{\circ} \mathrm{C} 5$ min before the selection time and attached to MidiMACS magnet area, and columns were washed three times with ice cold PBS containing EDTA and $2 \%$ bovine serum albumin (PBS-EDTA-BSA buffer) solution. Due to the hydrophilic structure of the column, buffer solution passed through the columns easily and quickly. Cells were passed through the column after this priming.

To eliminate the residual non-CD34 cells, columns were washed with buffer solution twice. Then, the column was taken out of the magnet area and $5 \mathrm{ml}$ of buffer solution was added to the column, which was placed over a $15 \mathrm{ml}$ conical tube of appropriate size. By applying sudden force to the column piston, the CD34+ cells that were attached to magnetic beads were pushed into the collection tube. The force applied to the column pistol was critical for the CD34+ cell yield. A small portion of cells were taken for immunophenotypic analysis. For disattachment of MACS MultiSort beads, MultiSort Release Reagent ( $20 \mu \mathrm{l} / \mathrm{ml}$ ) was used, and cells were incubated at $+4^{\circ} \mathrm{C}$ for $10 \mathrm{~min}$. After cells were centrifuged at $400 \mathrm{xg}$, pellet was resuspended to $10^{7}$ cells/50 $\mu \mathrm{l}$. $30 \mu \mathrm{l}$ MACS MultiSort Stop Reagent was added for each $10^{7}$ cells. Cells were diluted in RPMI1640 before cell culture.

\section{CD34 Immunophenotyping of CD34-Selected Samples by Flow Cytometry}

Isotypic control (IgG1-FITC/lgG1-PE), CD34-FITC, CD34-PE and CD34-+Rhd123 tubes were labelled using the direct method. After incubation at room temperature for $15 \mathrm{~min}$, cells were washed with 
PBS-EDTA buffer solution twice. Cells were then analyzed by flow cytometry (EPICS XL-MCL, Beckman Coulter, Ltd), and the results were evaluated with System 2.0 software.

\section{Cell Culture and Assays for CD34+ Cells}

\section{LTC-IC (Long-Term C ulture-Initiating C ells)}

Even though there have been many developments for determination of the precursor and progenitor cells of hematopoietic cells, there is still no specific analytical means of determining the bone marrow repopulating cells. Cells obtained through LTC-IC are the most primitive cells that can be analyzed by in vitro functional assays. The validity of the LTC-IC assays is dependent on the existence of a linear relationship between the endpoint measured (clonogenic cell output as assessed after 5 weeks of culture) and the number of LTC-IC in the original test suspension down to limiting numbers of LTC-IC $[6,7]$. We used the limiting dilution method for LTCIC in order to evaluate the bone marrow renewal capacity of the cord blood CD34+ cells (Figure 1).

As feeder layer, a murine bone marrow stroma, M2-10B4 (ATCC, CRL 1972), known to release the necessary cytokines and growth factors, has been used [8,9]. M2-10B4 cells were fed with RPMI 1640 (Sigma, USA) cell culture medium with $10 \%$ fetal bovine serum (FBS) in cell culture flasks. After they became confluent in approximately one week, cells were irradiated with 15 Gy in ${ }^{137} \mathrm{Cs}$, trypsinized, washed and diluted in IMDM (Iscove's Modified Dulbecco's Medium) containing 10\% FBS (Sigma), $10 \%$ horse serum (Sigma), and 10-6 M hydrocortisone (Sigma). After cell count and adjustment of cell concentration, cells were distributed to 96- well plates, 15,000 - 22,000 cells/well. These feeder layer plates were kept ready with change of medium twice a week and were used in two weeks. CD34+ cord blood cells, selected with MACS magnetic beads, were cultured on these M2-10B4 feeder layers with six different dilutions $[1,10,100,300,1000,5000)$ in 16 wells for each concentration. Cultures were incubated in a humidified atmosphere containing 5\% $\mathrm{CO} 2$ in air at $37^{\circ} \mathrm{C}$. Culture plates were fed with half medium changes for five weeks. CAFCs (Cobblestone Area Forming Cells) were defined as cell groups of at least 15 cells under phase contrast inverted microscope with typical appearance at weeks 5-8. LTC-IC absolute counts with LDA were evaluated as described previously [10-12].

\section{MethoC ult GF + Semi-Solid Culture System}

MethoCult obtained from Stem Cell Technologies, Canada was used for colony-forming unit (CFU) assays. This culture media consists of methyl cellulose, FBS, BSA, 2-mercaptoethanol, L-glutamine, recombinant human ( $r h$ ) stem cell factor, rh granulocyte-macrophage colony-stimulating factor (GM-CSF), rh interleukin (IL)-3, rhIL-6, rhG-CSF, and rhErythropoietin. Cells were seeded in 300 $\mathrm{CD} 34^{+}$cell $/ \mathrm{ml}$ concentration. Colonies were first observed between days 12-15 under inverted microscope and counted on day 14 when the number of colonies was at the maximum. Two independent scientists counted the colonies on the same day and mean values were reported. Groups containing more than 40 cells were considered as colonies. CFU-GM, BFU-E (Burst Forming Unit-Erythroid) and CFU-GEMM (granulocyte, erythroid, monocyte, macrophage) colonies were differentiated according to the following criteria: CFU-GM colonies were observed as transparent, flat and non hemoglobinconsisting colonies, and as very dense colonies; BFU-E were discriminated easily as dense, with color changing from orange to red due to their hemoglobin content; CFU-GEMM could be determined easily, since they contained both erythroid and myeloid cells with both transparent and orangered hemoglobin-containing cells [12].

\section{Results}

Immunophenotypic characteristics of the cord blood samples are summarized in Table 1 . The CD45 percentage of the cord blood mononuclear cells was lower compared to bone marrow or peripheral blood due to the presence of nucleated erythrocytes in the analysis area. CD71 was used to determine the percentage of nucleated erythrocytes and found to be $10.2 \pm 1.78 \%$.

The mononuclear cell content and CD34 values before and after selection are summarized in Table 2 . Mean CD34 percentage before positive selection with MACS beads was $1.2 \pm 0.26 \%$, and there was a purity of $73.64 \pm 9.12 \%$ after selection.

CAFCs were obtained after 5 weeks of culture. After CAFC was observed, cells from the CAFCpositive wells were transferred to MethoCult GF+ semi-solid cultures to observe the colonies on days 14-15. 


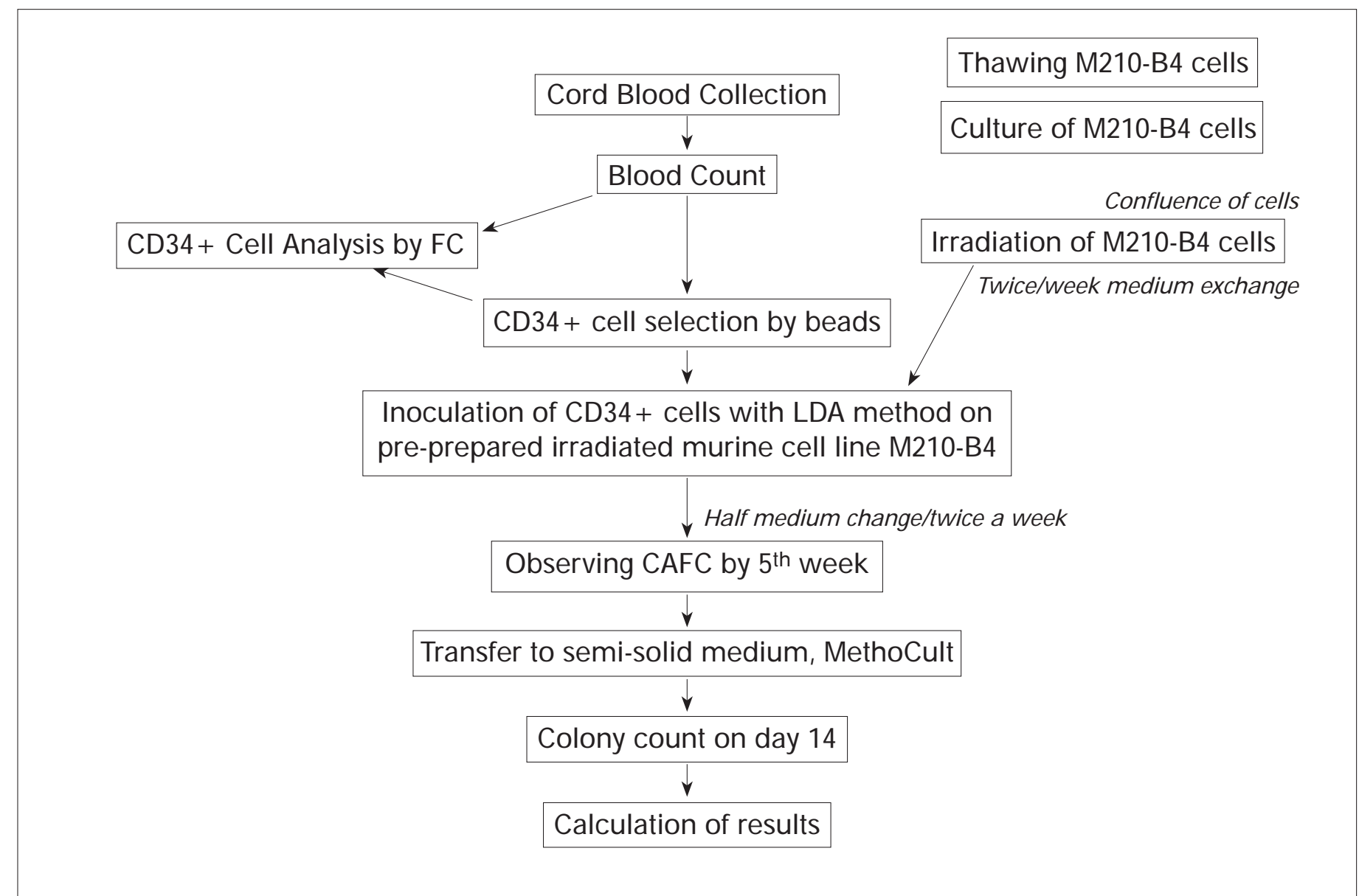

Figure 1. A summary of the LTC-IC by LDA method. FC: Flow cytometry, LDA: Limiting dilution assay, CAFC: Cobblestone area forming cells

Table 1. Immunophenotypic characteristics of cord blood cells before selection

\begin{tabular}{|c|c|c|}
\hline Immunophenotypic Markers & \multicolumn{2}{|c|}{ Positivity (\%) + /- SD 1} \\
\hline CD34 (Stemness marker) & & $1.2 \pm 0.26$ \\
\hline CD45 (Pan leukocyte marker) & & $84.8 \pm 2.0$ \\
\hline CD38 (Activation marker, positive c & on SCs) & $57.0 \pm 7.45$ \\
\hline CD71 (Activation marker, positive o & on erythroid cells) & $10.2 \pm 1.78$ \\
\hline CD90 (Stem cell marker) & & $0.4 \pm 0.39$ \\
\hline HLA-DR (MHC Class II marker) & & $11.3 \pm 1.31$ \\
\hline CD135 (FLT3-Stem cell marker) & & $11.9 \pm 3.11$ \\
\hline \multicolumn{3}{|c|}{$\begin{array}{l}\text { CD45 percentage is less than } 90 \% \text { due to presence of nucleated erythrocytes in } \\
\text { cord blood }\end{array}$} \\
\hline \multicolumn{3}{|c|}{$\begin{array}{l}\text { Table 2. MNC and CD } 34 \text { levels before and after CD34+ cell selection } \\
\text { with MACS beads }\end{array}$} \\
\hline & Before Selection & After Selection \\
\hline Percentage of CD34 & $1.2 \pm 0.26$ & $73.64 \pm 9.12$ \\
\hline $\begin{array}{l}\text { Mononuclear Cell Count } \\
(\times 10 \% / \mathrm{ml})\end{array}$ & $1.8 \pm 0.65$ & $0.19 \pm 0.12$ \\
\hline
\end{tabular}

Only $60 \%$ of the MethoCult GF+ cultures obtained from CAFC of LTC-IC gave rise to HPP-Q (High Proliferative Potential-Quiescent) colonies, while all cultures had BFU-E, GM and GEMM colonies by day 14, as shown in Figure 2. LTC-IC numbers calculated as LTC-IC/CD34+ cells are presented in Table 3.

\section{Discussion}

Although the number of articles on cord blood LTC-IC are somewhat limited, our LTC-IC/CD34+ cell numbers were lower compared to some of the published studies $[13,14]$, but results of several studies were consistent with ours [15]. There are several controversial issues, which will be discussed in the remainder of this article.

LTC-IC assay with limiting dilution is relatively easier than the other LTC-IC assays, since the preprepared murine bone marrow stromal cell line plates can be used in five weeks, and counting CFUs is easier than counting CAFCs. This method is 
used as an "ex vivo expansion" assay for CD34 ${ }^{+}$ cells. When only the CAFCs were scored, a higher frequency of LTC-IC was estimated in cultures utilizing the M2-10B4 cell line [16].

Table 3. LTC-IC counts from CD34+ selected cord blood cells (range: 1261-2906, mean: 1966 \pm 808)

\begin{tabular}{lc}
\hline Samples & LTC-IC/CD34+ cells \\
\hline 1 & 2705 \\
2 & 2906 \\
3 & 2580 \\
4 & 1649 \\
5 & 1781 \\
6 & 1280 \\
7 & 1649 \\
8 & 2499 \\
9 & 1350 \\
10 & 1261 \\
Mean Value & $1966 \pm 808$ \\
\hline
\end{tabular}

The role of LTC-IC in long-term engraftment is unknown; however, they are the most primitive progenitors that can be detected in an in vitro assay. Among the cultured LTC-IC, some cells remain quiescent and others are thought to be triggered into proliferation. Clinical studies have been performed with ex vivo expanded cells from autologous stem cell harvests; however, it is unknown if the longterm engraftment was achieved from ex vivo expanded cells including LTC-IC or from surviving stem cells in patients.

A recent study reported that type of stromal feeder layer used in LTC-IC LDA affects the determination of LTC-IC frequencies in uncultured cells and also has a significant effect on cultures. In their study, Nadali et al. [16] noted that proliferative capacity of CB LTC-IC can be strongly influenced by culture conditions and that the frequency of LTC-IC estimated using these cell lines as stromal support is not identical. They emphasized that long-term

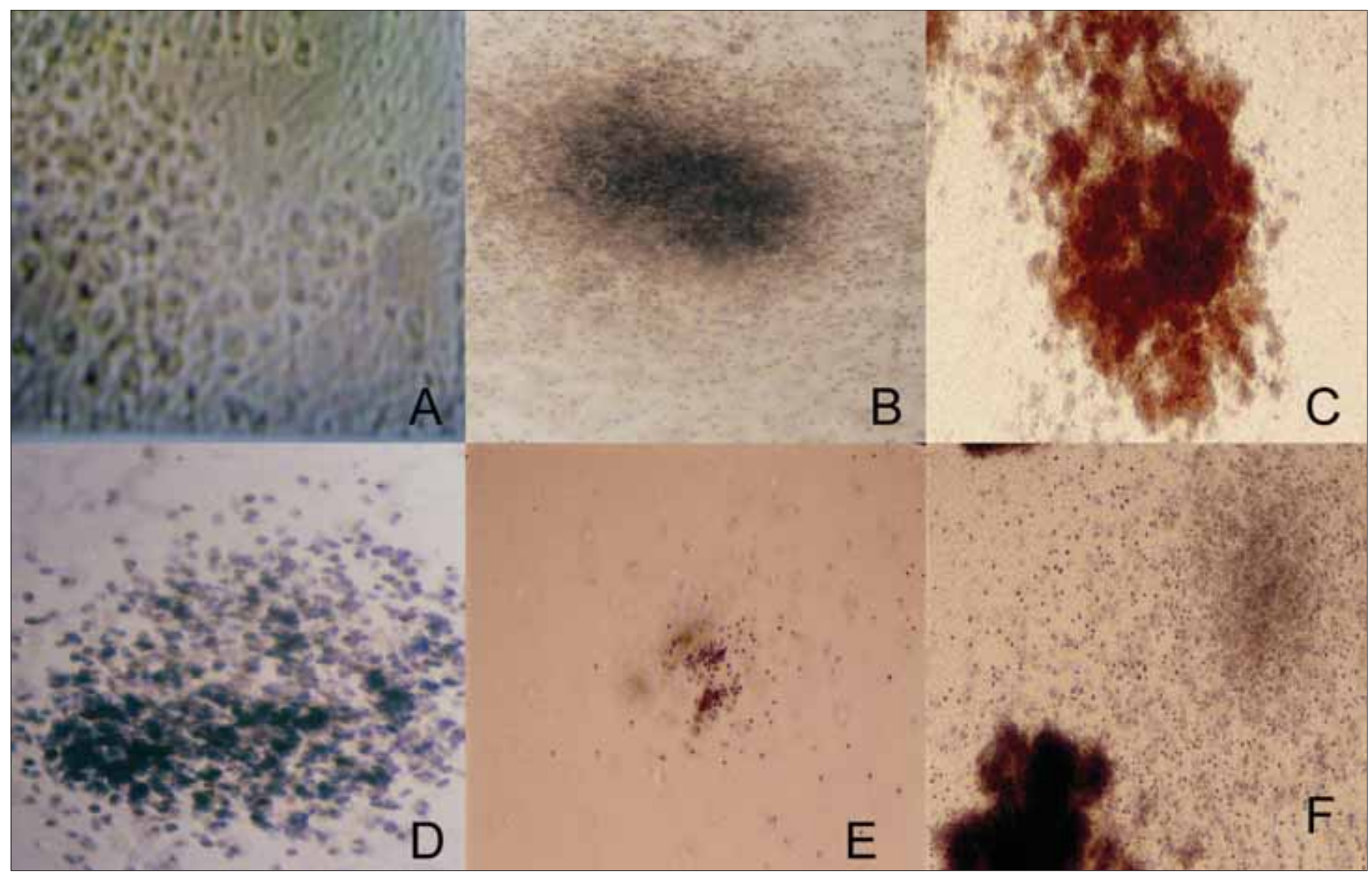

Figure 2. CAFC and CFUs obtained from CD34+ cord blood cells are shown. CAFC were measured at week 5 and then cells were transferred to MethoCult, a semicellulose commercial media used for CFU assays. CFUs were counted on day 12 (week 7). A. Cobblestone Area Forming Cells (CAFCs) after week 5. B. CFU-GEMM: Colony Forming Unit-GranulocyteErythroidMonocyteMacrophage. C. BFU-E: Burst Forming Unit - Erythroid. D. Giemsa-stained BFU-E. E. A HPP-Q (High Proliferative Potential-Quiscent) colony. F. A BFU-E and CFU-GM are seen in a nearby area of the petri dish in MethoCult media 
culture on stromal support other than normal bone marrow can strongly influence the in vitro behavior of LTC-IC and may lead to errors in estimating the frequency of LTC-IC. Even though it is easier to grow and maintain cell lines such as M2-10B4, one can not be sure if they are releasing all of the necessary cytokines, chemokines and growth factors.

Due to use of various cell lines or bone marrow stromal cells, there have been diverse outcomes from different laboratories worldwide [17-19]. It has been published that CD34+ purification is one of the prerequisites for successful expansion. However, it is also the reason for the lower number of colonies counted in this assay, since the cells such as monocytes and lymphocytes, which release different growth factors, cytokines and chemokines, are not present to help the stem cell proliferation.

The temperature of the LTC-IC was kept at $35^{\circ} \mathrm{C}$ in our study. Some of the earlier studies have used $37^{\circ} \mathrm{C}$ for the first three to four days and then switched to $33^{\circ} \mathrm{C}$, but most of these studies were for murine LTC-IC [17]. Podesta et al. [19] published that temperature has an effect on colony growth of human progenitor cells, and LTC-IC performed at $37^{\circ} \mathrm{C}$ gave rise to more colonies than those at $33^{\circ} \mathrm{C}$. One of the reasons for the lower numbers of colonies in our study could be the temperature.

Clinical trials of ex vivo expanded cord blood are under way in the United States and Europe, using CD34+ selected cells expanded in Teflon culture bags and non-selected cord blood mononuclear cells expanded in bioreactors. These experiments are testing different combinations of cytokines to determine the optimal dose of cytokines to lead to improved stem cell engraftment [20].

STAT-5 is a signal tranducer and activator of transcription, involved in self renewal, proliferation and apoptosis of hematopoietic cells. Schepers et al. [21] performed STAT5 RNAi in sorted cord blood cells by lentiviral transduction, and investigated the effects of STAT5 downmodulation on normal stem/ progenitor cell compartment. They showed that LDAs with cord blood had a 3.9-fold reduction in progenitor numbers. Their data indicated that STAT5 expression is required for the maintenance and expansion of primitive hematopoietic stem and progenitor cells, both in normal and leukemic hematopoiesis [21]. STAT5 and expression of other transcription factors may also have played a role in the lower number of colony counts in our study.
Even though there has been some progress in the standardization of the LTC-IC culture methods, a more standardized approach will help us to achieve better results for ex vivo expansion of hematopoietic cells. We believe that identification of defined conditions for extensive and rapid amplification of LTC-IC would help to analyze the benefit of these cells for therapeutic applications in the future. We now know that standardization of the method with human originated feeder layer cells and use of animal-free medium are necessary to use these cells in therapeutic applications. By implementing the LDA method for LTC-IC in our laboratory, we have taken a step forward for the ex vivo expansion of stem cells and will proceed with further research in the future with more studies on cell-to-cell contact and cytokine/chemokine effect on LTC-IC.

We also suggest that more information about the in vivo scenario can be gained with further insight into the use of human cord blood stromal cells or HUVEC (human umblical vein endothelial cells) as feeder layers and with exploration of in vitro behavior of LTC-IC for CFC production.

\section{Acknowledgments}

The authors thank Zeynep Kamil Obstetrics Hospital Delivery Room personnel, especially Dr. Vedat Dayıoğlu and Dr. Ateş Karateke, for their help in cord blood collection; Dr. Pakize I. Tarzi Laboratuvarlan for permission to use their flow cytometry system; and Marmara University Blood Bank personnel for their help and kindness during the work in the stem cell laboratory. Special thanks to Aslı Önder Gül for the technical assistance with flow cytometry and to Prof. Dr. Sami Kart, Yeditepe University Medical Faculty, for careful reading of the manuscript.

\section{Conflict of interest}

No author of this paper has a conflict of interest, including specific financial interests, relationships, and/or affiliations relevant to the subject matter or materials included in this manuscript.

\section{References}

1. Ploemacher RE, van der Sluijs JP, Voerman JS, Brons $\mathrm{NH}$. An in vitro limiting dilution assay of long term repopulating hematopoietic stem cells in the mouse. Blood 1989;74:2755-63.

2. Weaver A, Ryder WD, Testa NG. Measurement of long term culture initiating cells (LTC-ICS) using limiting 
dilution: comparison of endpoints and stromal support. Exp Hematol 1997;25:1333-8.

3. Cashman C, Bockhold K, Hogge DE, Eaves AC, Eaves CJ. Sustained proliferation, multi-lineage differentiation and maintenance of primitive human hematopoietic cells in NOD/SCID mice transplanted with human cord blood. Br J Haematol 1997;98:1026-36.

4. Frisan T, Levitsky V, Masucci M. Limiting dilution assay. Methods Mol Biol 2001:174:213-6.

5. Burroughs], Gupta P, BlazarBR, Verfaillie CM. Diffusible factors from the murine cell line M2-10B4 support human in vitro hematopoiesis. Exp Hematol 1994; 22:1095-101.

6. Punzel M, Moore KA, Lemischka IR, Verfaille CM. The type of stromal feeder used in limiting dilution assays influences frequency and maintenance assessment of human long term culture initiating cells. Leukemia 1999;13:92-7.

7. Traycoff CM, Kosak ST, Grigsby S, Srour EF. Evaluation of ex vivo expansion potential of cord blood and bone marrow hematopoietic progenitor cells using cell tracking and limiting dilution analysis. Blood 1995;85:2059-68.

8. Eaves C, Miller C, Cashman J, Conneally E, Petzer A, Zandstra P, Eaves A. Hematopoietic stem cells: inferences from in vivo assays. Stem Cells 1997;15:1-5.

9. Ploemacher RE, van der Sluijs JP, van Beurden AJ, Baert MRM, Chan PL. Use of limiting-dilution type longterm marrow cultures in frequency analysis of marrow repopulating and spleen colony-forming hematopoietic stem cells in the mouse. Blood 1991;78:2527-33.

10. Dexter TM, Allen TD, Lajtha LG. Conditions controlling the proliferation of haemopoietic stem cells in vitro. J Cell Physiol 1977;91:335-44.

11. Gartner S, Kaplan HS. Long-term culture of human bone marrow cells. PNAS 1980;77:4756-9.

12. Miller $\mathrm{CL}$, Lai $\mathrm{B}$. Human and mouse hematopoietic colony-forming cells assays. In: Helgason CD, Miller $\mathrm{CL}$, editors. Basic Cell Culture Protocols 3, Methods in Molecular Biology. Vol 290. Totowa, NJ : Humana Press, 2005:71-89.
13. Pettengell R, Luft T, Henschler R, Hows JM, Dexter TM, Ryder D, Testa NG. Direct comparison by limiting dilution analysis of long-term-culture-initiating cells in human bone marrow, umbilical cord blood, and blood stem cells. Blood 1994;84:3653-9.

14. Denning-Kendall PA, Nicol A, Horsley H, Donaldson C, Bradley $B$, Hows JM. Is in vitro expansion of human cord blood cells clinically relevant? Bone Marrow Transplant 1998;21:225-32.

15. Hao QL, Shah AJ, Thiemann FT, Smorgorzewska EM, Crooks GM. Extended long-term culture reveals a highly quiescent and primitive human haemopoietic progenitor population. Blood 1996;88:3306-13.

16. Nadali G, de Wynter EA, Perandin F, Tavecchia L, Vincenzi C, Ambrosetti A, Fornale M, Perona G, Pizzolo G, Testa NG. Regulation of the proliferative potential of cord blood long-term culture-initiating cells (LTC-IC) by different stromal cell lines: implications for LTC-IC measurement. Haematologica 1998;83:1059-65.

17. Sutherland HJ, Cashman JD, Henkelman DH, Eaves AC, Eaves CJ . Functional characterization of individual human hematopoietic stem cells cultured at limiting dilution on supportive marrow stroma. PNAS 1989;87:3584.

18. Sutherland HJ, Eaves CJ, Lansdorp PM, Thaker JD, Hogge DE. Different regulation of primitive human hematopoietic cells in long term cultures maintained on genetically engineered murine stromal cells. Blood 1991; 78:666-72.

19. Podesta M, Piaggio G, Pitto A, Zocchi E, Soracco M, Frassoni F, Luchetti S, Painelli E, Bacigalupo A. Modified in vitro conditions for cord blood derived long term culture iniating cells. Exp Hematol 2001;29:309-34.

20. Moore MAS. Umblical cord blood: an expandable resource. J Cl 2004;105:855-6.

21. Schepers H, van Gosliga D, Wierenga ATJ , Eggen BJ L, Schuringa JJ, Vellenga E. STAT5 is required for long term maintenance of normal and leukemic human stem/progenitor cells. Blood 2007;110:2880-8. 